\title{
ARTI PENTING DIBENTUKNYA PENGADILAN TATA USAHA NEGARA
}

\author{
Nama Mahasiswa : Diky Ramadhan \\ Email : dikyramadhan87@gmail.com
}

No BP : 1810003600426

Universitas Ekasakti Padang

\section{A. PENDAHULUAN}

Negara RI adalah negara hukum, adapun salah satu ciri negara hukum adalah adanya kekuasaan kehakiman yg merdeka termasuk di dalamnya ada peradilan Natausaha Usah Negara,dibentuk dalam ranggka memberikan perlindungan kepada masyarakat pencari keadilan, yg merasa dirinyanya dirugikan akibat suatu Keputusa Tata Usaha Negara.Berbagai macam KTUN dapat digugat ke PTUN,hal ini disebabkan berbagai macam perbuatan pecabat atau usaha negara seperti perijinan (vergunning),dispensasi , konsesi, dan pengurusan surat-surat dituan kan dalam bentuk keputusan pejabat (beschikking) salah satu KTUN yang dapat menjadi objek sengketa di pengadilan tata usaha negara adalah izin dibidang lingkungan.

Persyaratan-persyaratan yg terkandung dalam izin merupakan pengendali dalam memfungsikan izin itu sendiri, Dalam konteks pengelola lingkungan hidup, maka subtansi pengelola lingkungan hidup hanya dapat berhasil menunjang terwujudnya sistem pembangunan berkelanjutan,apabila administrasi pemerintah dapat berfungsi secara efektif dan terpadu. Salah satu sarana yuridis administratif untuk mencegah dan menanggulangi adanya pencemaran dan perusakan lingkungan adalah melalui sistem perizinan. Perizinan 
adalah merupakan instrumen kebijaksanaan lingkungan yang paling mendasar yang ditujukan untuk dapat menjaga kepentingan lingkungan dan keseimbangan ekologis, yang pada akhirnya tetap dapat dinikmati oleh generasi sekarang dan generasi mendatang.

Dalam prakteknya sistem perizinan belum mampu berfungsi sebagai pengendali agar suatu usaha dan/atau kegiatan tidak menimbulkan pencemaran dan kerusakan lingkungan. Suatu usaha dan/atau kegiatan yang diperkirakan mempunyai potensi besar dan menimbulkan dampak negatif terhadap lingkungan dinilai layak lingkungan dan diberikan izin. Dalam kasus lain, suatu usaha dan/ atau kegiatan yang telah dilengkapi dengan izin, dalam pelaksanaannya seringkali menimbulkan dampak berupa pencemaran dan/atau kerusakan lingkungan. Dalam hal yang demikian, organisasi lingkungan hidup dapat menggugat pejabat yang mengeluarkan KTUN untuk usaha dan/atau kegiatan yang berpotensi atau telah menimbulkan dampak negatif terhadap lingkungan hidup tersebut ke Pengadilan TUN. Dalam sengketa lingkungan tersebut, organisasi lingkungan hidup memohon agar KTUN untuk usaha dan/atau kegiatan tersebut dinyatakan batal atau tidak sah dan memerintahkan kepada tergugat untuk mencabut KTUN tersebut.

Maksud adanya peradilan adalah memberikan keadilan kepada para pihak dan demikian menghilangkan sengketa. Sengketa merupakan sesuatu yang mengganggu ketentraman, tata tertib, dan kedamaian masyarakat, sehingga keseimbangan masyarakat tergoncang karenanya. Dengan adanya peradilan termasuk PTUN diharapkan kegoncangan dalam masyarakat akibat kerusakan atau pencemaran lingkungan hidup dapat dipulihkan. Namun demikian, sengketa- sengketa lingkungan yang telah diselesaikan oleh PTUN dalam kenyataannya belum menghilangkan konflik yang ada. Kegiatan dan/atau usaha yang berpotensi atau telah menimbulkan pencemaran dan kerusakan lingkungan tetap 
mengantongi izin dan tetap menjalankan usaha dan/atau kegiatannya. Pencemaran atau kerusakan lingkungan masih terus berlangsung yang menimbulkan ancaman terhadap kelestarian lingkungan.

\section{B. PEMBAHASAN}

1. Arti Penting Dibentuknya Hukum Tata Usaha Negara

Sebagai berwujud dan Indonesia sebagai Negara hukum yang menjunjung tinggi nilai-nilai keadilan, kepastian hukum dan Hak Asasi Manusia (HAM) dan untuk melaksanakan amanat Pasal 24 ayat (2) Undang-Undang Dasar 1945 (Perubahan) juncto Pasal 10 ayat (1) huruf d Undang-Undang Nomor 14 Tahun 1970 tentang Kekuasaan Kehakiman yang telah diganti dengan Undang-Undang Nomor 48 Tahun 2009 juncto Pasal 6 ayat (1) Undang-undang Nomor 5 Tahun 1986 tentang Peradilan Tata Usaha Negara sebagaimana telah diubah dengan Undang-Undang Nomor 9 Tahun 2004 dan Perubahan Kedua dengan UndangUndang Nomor 51 Tahun 2009, maka dibentuklah Pengadilan Tata Usaha Negara Mataram berdasarkan Keputusan Presiden RI (Keppres) Nomor 2 Tahun 1997 tentang Pembentukan Pengadilan Tata Usaha Negara Banda Aceh, Pakanbaru, Jambi, Bengkulu, Palangkaraya, Palu, Kendari, Yogyakarta, Mataram, Dan Dili.

Adapun tujuan dibentuknya Peradilan Tata Usaha Negara (PERATUN) adalah untuk mewujudkan tata kehidupan negara dan bangsa yang sejahtera, aman, tenteram serta tertib yang dapat menjamin kedudukan warga masyarakat dalam hukum dan menjamin terpeliharanya hubungan yang serasi, seimbang, serta selaras antara warna Negara dengan aparatur di bidang tata usaha Negara. 


\section{Kewenangan PTUN}

Perlu dijelaskan terlebih dahulu mengenai arti kewenangan. Menurut Ateng Syafrudin sebagaimana dikutip dari Nuryanto A. Daim, berpendapat ada perbedaan antara pengertian kewenangan dan wewenang. Kewenangan adalah apa yang disebutkekuasaan formal, yaitu kekuasaan yang diberikan oleh undang-undang, sedangkan wewenang hanya mengenai seuatu "onderdeel"(bagian) tertentu saja dari kewenangan. Di dalam kewenangan terdapat wewenang-wewenang (rechtshe voegdheden). Kewenangan yang dimiliki oleh PTUN adalah kewenangan berdasarkan UU No. 5 Tahun 1986 tentang Peradilan Tata Usaha Negara yang sekaligus merupakan landasan operasional .

Pendapat lain mengenai kompetensisebagai istilah lain yang sering pula digunakan untuk merujuk kekuasaan atau kewenangan lembaga. Kompetensi berasal dari bahasa Latin yaitu "competentia" yang berarti "hetgeen aan jemand toekomt" ( apa yang menjadi wewenang seseorang), yangdalam bahasa Indonesia hal tersebut sering diartikan dengan "kew enangan" atau "kekuasaan atau hak" yang dikaitkan dengan badan yang menjalankan kekuasaan kehakiman, sehingga badan tersebut menjadi“competence".

Rochmat Soemitro menyebutkan, sengketa timbul antara dua pihak yang mengganggu serta menimbulkan gangguandalam tata kehidupan bermasyarakat, dan untuk menyelesaikan sengketa perlu ada suatubantuan dari pihak ketiga yang bersikap netral dan tidak memihak. Pengadilan harus dapat mengatasi dan menyelesaikan sengketa secaraadil, untuk itu masyarakat atau pihak yang bersengketa harus memiliki kepercayaan bahwa Pengadilan akan menyelesaikan sengketa secara adil. 
Pasal 47 UU No. 5 Tahun 1986 tentang Peradilan Tata Usaha Negara menyebutkan bahwa pengadilan bertugas dan berwenang memeriksa, memutus dan menyelesaikansengketa tata usaha negara . Pembahasan mengenai kewenangan yang dimiliki berkaitan erat dengan obyek sengketa yang harus diperiksa, diputus dan diselesaikan .

Obyek sengketa yang diperiksa adalah, penetapan tertulis yang dikeluarkan oleh Badan atau Pejabat Tata Usaha Negara yang berisi tindakan hukum tata usaha negara yangbersifat konkrit, individual, final dan menimbulkan akibat hukum bagi seseorang atau badan hukum perdata.

Sengketa tata usaha negara dapatdikelompokkan menjadi 2 (dua), pertama sengketa intern menurut Wicipto Setiadi,menyangkut persoalan kewenangan pejabat Tata Usaha Negara dalam satu instansi atau kewenangan antar departemen / instansi lainnya, yang disebabkan tumpang tindihnya kewenangan, sehingga menimbulkan kekaburan kewenangan. Kedua, sengketa ekstern menurut Sjachran Basah dalam VictorYaved Neno adalah sengketa antara administrasi negara dan rakyat adalah perkaraadministrasi yang menimbulkan sengketa antara administrasi negara dengan rakyat dengan unsur yang bersumber dari unsur peradilan administrasi murni.

Merujuk pada isi Pasal 47 dan Pasal 1 huruf c UU No. 5 Tahun 1986 tentang Peradilan Tata Usaha Negara, secara jelastelah ditegaskan bahwa kewenangan yang dimiliki adalah untuk memeriksa, memutus dan menyelesaikan sengketa di bidang tata usaha negara. 
Didalam pasal 21 ayat (1) UU Nomor 30 tahun 2014 tentang administrasi Pemerintahan menyebutkan bahwa pengadilan berwenang menerima, memeriksa, dan memutuskan ada atau tidak unsur penyalahgunaan wewenang oleh pejabat pemerintah. Badan atau Pejabat Pemerintahan dapat mengajukan permohonankepada Pengadilan untuk menilai ada atautidak ada unsur penyalahgunaan wewenang yang dilakukan oleh Pejabat Pemerintahan. Hal ini berbeda dengan isi Pasal 47 UU No. 5 Tahun 1986, sebagaimana dikemukakansebelumnya, dalam Pasal 21 ayat (1) UU No.30 Tahun 2014 disebutkan PTUN menerima, memeriksa dan memutus ada atau tidaknya unsur penyalahgunaan wewenang, yang secara jelas hal tersebut bukan sengketa tata usaha negara.

Rumusan isi kedua pasal tersebut berbeda, yang dapat timbul pemikiran bahwa : satu, kewenangan PTUN menjadi lebih luas, tidak sekedar memeriksa, memutus dan menyelesaikan sengketa tata usaha negara,tetapi juga menilai ada atau tidak ada unsur penyalahgunaan wewenang yang dilakukan oleh Pejabat Pemerintahan. Kedua, bahwa terhadap putusan Pengadilan mengenai ada atau tidaknya penyalahgunaan wewenang tersebut, dapat diajukan permohonan bandingke Pengadilan Tinggi Tata Usaha Negara yangputusannya bersifat final dan mengikat.

Kedua hal tersebut merupakan perluasan terhadap kewenangan PTUN, yaitu tidak hanya memeruksa, m e m u t u s k a n d a n menyelesaikan sengketa tata usaha negara saja, tetapi cakupan kewenangan yang lebih luas. Bertambah luasnya kewenangan PTUN ini menimbulkan pertanyaan, mengapa untukmenilai ada atau tidaknya penyalahgunaanwewenang oleh Pejabat Pemerintahan, memerlukan keputusan dari lembaga Peradilan dan juga dapat diajukan banding ke Pengadilan 
Tinggi Tata Usaha Negara.

Perlu dilihat sejarah pembentukan UU tentang PTUN, yang berkaitan dengan ruanglingkup kewenangan. Ruang lingkup kewenangan Peradilan Tata Usaha Negarayang dicantumkan pada Draft RUU Peratun versi LPHN (RUU II Tahun 1976 ),disebutkan bahwa lingkup kewenangan Peratun tidak hanya terbatas pada keputusan tertulis yang bersifat konkret, indivdual, final tetapi juga mencakup semua tindakan pemerintah yang dianggap melawan hukum (onrechtmatige overheidsdaad).

Pada Draft RUU Peratun versi LPHN atau RUU II Tahun 1976, Pemerintah sudah memasukkan semua tindakan pemerintah yang dianggap melawan hukum sebagaiobyek sengketa yang dapat diperiksa, diputusdan diselesaikan oleh PTUN. Namun yang diatur dalam UU No. 5 Tahun 1986 adalah "sengketa tata usaha negara" artinya berbeda dengan yang diusulkan dalam Draft RUU Peratun versi LPHN. Ternyata apa yang pernah dicantumkan dalam Draft RUU Peratun versi LPHN justru di muat dalam UUNo. 30 Tahun 2014 tentang Administrasi Pemerintahan dan merupakan kewenanganPTUN.

Isi Pasal 21 UU No. 30 Tahun 2014tentang Administrasi Pemerintahan sebagai upaya Pemerintah untuk memperluas kewenangan PTUN sehingga tidak hanya sebagai peradilan tata usaha negara tetapi jugasebagai peradilan administrasi.

Untuk mengetahui pemikiran atau latar belakang kemungkinan upaya Pemerintah memperluas kewenangan PTUN, dapat dilihatpendapat para ahli hukum terkait hal tersebutt erutama pada saat penyusun RUU PERATUN. Mengenai hal tersebut Wicipto Setiadi mengemukakan pendapat, mengapadalam UU No. 5 
Tahun 1986 tentang PTUN tidak mengatur sengketa intern yaitu sengketa antar persoalan pejabat Tata Usaha Negara dalam satu departemen / instansi yang disebabkan adanya tumpang t indih kewenangan? Ada 2 (dua) pendapat yang disampaikan, pertama, adanya kekhawatiran Pemerintah terhadap kinerja aparat pemerintahan atau, kedua ada kesengajaanoleh Pemerintah untuk membatasi diri pada lingkup sempit, dengan tidak menutupkemungkinan terjadi perluasan kewenangan PTUN di masa mendatang. Sehingga tidak sekedar PTUN tetapi sebagai peradilan administrasi yang berarti menjangkau setiap perbuatan atau tindakan hukum publik oleh Pemerintah

Berawal dari pendapat Wicipto Setiadi diatas, dan adanya UU No. 30 Tahun 2014 tentang Administrasi Pemerintahan sebagai undang-undang pertama dalam bidang hukumadministrasi negara sekaligus sebagai hukumformil terhadap PTUN, bahwa memang ada kemungkinan untuk memperluas kewenanganPTUN yang diikuti dengan pelbagai bentuk tindakan hukum Pemerintah serta syarat dan akibat hukumnya.

\section{Dasar Hukum Pembentukan Peradilan Tata Usaha Negara (PERATUN)}

a) Keputusan Presiden RI (Keppres) Nomor 2 Tahun 1997 tentang Pembentukan Pengadilan Tata Usaha Negara Banda Aceh, Pakanbaru, Jambi, Bengkulu, Palangkaraya, Palu, Kendari, Yogyakarta, Mataram, Dan Dili.

b) Undang-Undang Nomor 5 Tahun 1986, Tentang Peradilan Tata Usaha Negara.

c) Undang-Undang Nomor 9 Tahun 2004, Tentang Perubahan Atas UndangUndang Nomor : 5 Tahun 1986, Tentang Peradilan Tata Usaha Negara.

d) Undang-Undang Nomor 51 Tahun 2009, Tentang Perubahan Kedua Atas UndangUndang Nomor : 5 Tahun 1986, Tentang Peradilan Tata Usaha Negara 
4. Fungsi PTUN dalam Memberikan Perlin- dungan terhadap Kelestarian Lingkungan

Fungsi PTUN dalam penyelesaian sengketa lingkungan tidak hanya memberikan perlindungan Dalam hal lingkungan hidup yang menderita karena telah terjadi pencemaran dan/atau kerusakan lingkungan hidup, maka lingkungan hidup diwakili oleh lembaga swadaya masyarakat (LSM) yang bergerak di bidang lingkungan hidup (organisasi lingkungan hidup) dapat menggugat pejabat dan/atau badan tata usaha negara ke Pengadilan TUN karena pejabat dan/atau badan yang bersangkutan telah memberikan izin kepada perusahaan yang kegiatannya potensial atau telah menimbulkan pencemaran dan/atau kerusakan terhadap lingkungan hidup. Dasar hak gugat organisasi lingkungan hidup adalah Pasal 92 Undang-Undang No. 32 Tahun 2009 tentang Perlindungan dan Pengelolaan Lingkungan Hidup yang menyebutkan bahwa:

(1) Dalam rangka pelaksanaan tanggung jawab perlindungan dan pengelolaan lingkungan hidup, organisasi ling- kungan hidup berhak mengajukan gugatan untuk kepentingan pelestarian fungsi lingkungan hidup.

(2) Hak mengajukan gugatan terbatas pada tuntutan untuk melakukan tindakan tertentu tanpa adanya tuntutan ganti rugi, kecuali biaya atau pengeluaran riil.

(3) Organisasi lingkungan hidup dapat mengajukan gugatan apabila memenuhi persyaratan:

(a) berbentuk badan hukum;

(b) menegaskan di dalam anggaran dasarnya bahwa organisasi tersebut didirikan untuk kepentingan pelestarian fungsi lingkungan hidup; dan 
(c) telah melaksanakan kegiatan nyata sesuai dengan anggaran dasarnya paling singkat 2 (dua) tahun. Diberikannya hak gugat terhadap organisasi lingkungan hidup, diharapkan organisasi lingkungan hidup tersebut dapat berperan dalam memperjuangkan upaya pelestarian lingkungan melalui pengadilan, termasuk di antaranya melalui Pengadilan Tata Usaha Negara. Menurut Aan Effendi, penyelesaian sengketa lingkungan melalui PTUN memiliki kelebihankelebihan bila dibandingkan dengan penyelesaian sengketa lingkungan di peradilan umum, baik itu melalui gugatan perdata maupun tuntutan secara pidana. Penyelesaian sengketa melalui PTUN adalah bertujuan untuk membatalkan izin lingkungan yang dimiliki oleh suatu usaha dan/atau kegiatan. Dengan dibatalkannya izin lingkungan tersebut berarti suatu usaha dan/atau kegiatan tidak dapat melanjutkan lagi usaha dan/atau kegiatannya sehingga sumber pencemarannya dapat dihentikan. Di dalam praktiknya, kelebihan yang disampaikan Aan Effendi ini sulit untuk direalisasikan melalui gugatan organisasi lingkungan hidup. Gugatan- gugatan yang diajukan oleh organisasi lingkungan hidup ke PTUN sering mengalami kegagalandalam memperjuangkan kelestarian lingkungan hidup.

Organisasi lingkungan hidup yang sering mengajukan gugatan ke PTUN untuk kepentingan kelestarian limgkungan hidup adalah wahana lingkungan hidup Indonesia. Ada beberapa gugatan yang diajukan oleh WALHI ke PTUN yang telah diputus oleh pengadilan yang telah memperoleh kekuatan hukum tetap. Berdasarkan analisis dari putusan-putusan PTUN yang memutus mengenai sengketa lingkungan yang digugat oleh organisasi lingkungan hidup, menunjukan bahwa PTUN belum memberikan perlindungan terhadap kelestarian lingkungan 
secara maksimal.

\section{PENUTUP}

1. Adapun tujuan dibentuknya Peradilan Tata Usaha Negara (PERATUN) adalah untuk mewujudkan tata kehidupan negara dan bangsa yang sejahtera, aman, tenteram serta tertib yang dapat menjamin kedudukan warga masyarakat dalam hukum dan menjamin terpeliharanya hubungan yang serasi, seimbang, serta selaras antara warna Negara dengan aparatur di bidang tata usaha Negara

2. Pasal 47 UU No. 5 Tahun 1986 tentang Peradilan Tata Usaha Negara menyebutkan bahwa pengadilan bertugas dan berwenang memeriksa, memutus dan menyelesaikan sengketa tata usaha negara . Pembahasan mengenai kewenangan yang dimiliki berkaitan erat dengan obyek sengketa yang harus diperiksa, diputus dan diselesaikan .

3. Fungsi PTUN dalam penyelesaian sengketa lingkungan tidak hanya memberikan perlindungan Dalam hal lingkungan hidup yang menderita karena telah terjadi pencemaran dan/atau kerusakan lingkungan hidup, maka lingkungan hidup diwakili oleh lembaga swadaya masyarakat (LSM) yang bergerak di bidang lingkungan hidup (organisasi lingkungan hidup) dapat menggugat pejabat dan/atau badan tata usaha negara ke Pengadilan TUN 


\section{DAFTAR PUSTAKA}

Darmini Roza dan Laurensius Arliman S, Peran Pemerintah Daerah Di Dalam Melindungi Hak Anak Di Indonesia, Masalah-Masalah Hukum, Volume 47, Nomor 1, 2018. https://doi.org/10.14710/mmh.47.1.2018.10-21

Laurensius Arliman S, Peranan Metodologi Penelitian Hukum di Dalam Perkembangan Ilmu Hukum di Indonesia, Soumatera Law Review, Volume 1, Nomor 1, 201. http://doi.org/10.22216/soumlaw.v1i1.3346.

Laurensius Arliman S, Peran Badan Permusyawaratan Desa di Dalam Pembangunan Desa dan Pengawasan Keuangan Desa, Padjadjaran Journal of Law, Volume 4, Nomor 3, 2017. https://doi.org/10.15408/jch.v4i2.3433.

Laurensius Arliman S, Penanaman Modal Asing Di Sumatera Barat Berdasarkan Undang- Undang Nomor 25 Tahun 2007 Tentang Penanaman Modal, Supremasi Hukum, Volume 1, Nomor 1, 2018. http://dx.doi.org/10.36441/hukum.v1i01.102 .

Laurensius Arliman S, Memperkuat Kearifan Lokal Untuk Menangkal Intoleransi UmatBeragama Di Indonesia, Ensiklopedia of Journal, Volume 1, Nomor 1, 2018, https://doi.org/10.33559/eoj.v1i1.18.

Laurensius Arliman S, Perkawinan Antar Negara Di Indonesia Berdasarkan Hukum Perdata Internasional, Kertha Patrika, Volume 39, Nomor 3, 2017, https://doi.org/10.24843/KP.2017.v39.i03.p03. 
Laurensius Arliman S, Partisipasi Masyarakat Di Dalam Pengelolaan Uang Desa PascaUndangUndang Nomor 6 Tahun 2014 Tentang Desa, Jurnal Arena Hukum, Volume 12, Nomor 2, 2019, https://doi.org/10.21776/ub.arenahukum.2019.01202.5.

Laurensius Arliman S, Mewujudkan Penegakan Hukum Yang Baik Di Negara Hukum Indonesia, Dialogica Jurnalica, Volume 11, Nomor 1, 2019, https://doi.org/10.28932/di.v11i1.1831.

Laurensius Arliman S, Mediasi Melalui Pendekatan Mufakat Sebagai Lembaga Alternatif Penyelesaian Sengketa Untuk Mendukung Pembangunan Ekonomi Nasional, UIR Law Review, Volume 2, Nomor 2, 2018, https://doi.org/10.25299/uirlrev.2018.vol2(02).1587

Laurensius Arliman S, Peranan Filsafat Hukum Dalam Perlindungan Hak Anak Yang Berkelanjutan Sebagai Bagian Dari Hak Asasi Manusia, Doctrinal, Volume 1, Nomor 2,2016 .

Laurensius Arliman S, Ni Putu Eka Dewi, Protection of Children and Women's Rights in Indonesiathrough International Regulation Ratification, Journal of Innovation, Creativity and Change Volume 15, Nomor 6, 2021.

Laurensius Arliman S, Gagalnya Perlindungan Anak Sebagai Salah Satu Bagian Dari Hak Asasi Manusia Oleh Orang Tua Ditinjau Dari Mazhab Utilitarianisme, Jurnal Yuridis, Volume 3, Nomor 2, 2016, http://dx.doi.org/10.35586/.v3i2.180.

Laurensius Arliman S, Tantangan Pendidikan Kewarganegaraan Pada Revolusi 4.0, Jurnal Ensiklopedia Sosial Review, Volume 2, Nomor 3, 2020. 